\title{
The One-Stop Shop Approach: New Public Management Model in Transition Countries
}

\author{
Kujtim Gashi (PhD Candidate) \\ University of Tirana, Albania \\ Prof. Ass. Dr. Ibrahim Krasniqi
}

University of Peja, Kosovo

Doi:10.19044/esj.2019.v15n1p185 ～URL:http://dx.doi.org/10.19044/esj.2019.v15n1p185

\begin{abstract}
Nowadays, One-stop shops (OSSs) are not rare, especially not in developed countries. In transition countries, they are currently very popular because the governments here are trying to address complaints about fragmentation in public service delivery. Specifically in those countries, the OSSs are faced very often with different problems beginning from the concept and design, followed by multiple implementation problems. This paper focuses on addressing the concept of development and new public management approach in transition countries using Kosovo as a case study. In addition, the paper seeks to determine drivers and barriers relevant to the strategic concept of adoption and implementation steps of OSSs in different public governance levels. OSS approaches are frequently established to bring win-win situations for citizens, clients, and service providers who are trying to find best solutions by delivering large number of services at lower cost. However, during the implementation phase, the political decision makers usually underestimate the complexities, costs, and risks of the OSS approach. This paper aims to establish general approach as a guide for the smooth implementation of OSS in order to avoid the unrealistic political and citizen expectations, conflicts, lack of resources, and dilemmas related to the OSS model that is most suitable for the certain region and governance level. During the research, the combined methodology was used by taking into consideration deductive approach and combining this with primary data collected through the interviews, face to face meetings, and, most importantly, comparing the different models from different countries in order to analyze and propose the most suitable model for Kosovo case of OSS. Whether or not the claimed benefits are achievable is an open question, and there are serious potential problems with the proposed system. Nevertheless, there is remarkably little evidence to support this claim.
\end{abstract}


Keywords: one-stop shop, public services, citizens, development

\section{Introduction}

Nowadays, rapid changes that have reformed the administrative procedures through the implementation of an e-Governance have become an on-going important process for governments around the world. The benefits of using ICT as a catalyst for increasing the efficiency of administrative procedures are well known and confirmed.

The implementation of computer-based information systems and providing a possibility for institutions to share data and documents among themselves will create conditions for introducing one-stop shop electronic services, which will lead to simplifying administrative procedures.

One-stop shops (OSS) or Points of Single Contact (PSCs) bring the benefits of e-government to citizens and entrepreneurs. They provide them with comprehensive information on applicable requirements and allow them to complete administrative procedures online, be it in their own country or in any other country. Consequently, they simplify the setting up and expansion of businesses in the Single Market and they also facilitate the overall procedures for the citizens (Anthopoulos, Siozos \& Tsoukalas, 2007).

Those points are meant to become the single interlocutor, by fulfilling coordinating role between service providers and competent authorities. Additionally, they are used for the gathering of information and the completion of the relevant procedures and formalities. Service providers have to comply with the procedure spelt out in the Republic of Kosovo in order to have access to or exercise a service activity. This is after they have been provided with all personal services, whether through the establishment of a business or by providing services across border from another state.

Reforms in the public sector aimed at improving service delivery have received considerable focus over the last decade, both within Kosovo and globally (Askim, Fimreite, Moseley \& Pederson, 2011). Driving this focus is an increased demand for governments to find ways of improving the efficiency and effectiveness of its service delivery. Delivering on these demands is prompting governments to adopt citizen-centric service delivery models which can significantly improve the customer experience by delivering outcomes based on citizens' needs, expectations and preferences, in addition to outcomes through enhanced service levels at the same or reduced cost (Aucoin, 2002).

In beginning the journey towards improving the citizen and customer experience, it is critical that public sector organizations should listen to their citizens and customers, understanding who they are, the interactions that they have, and their awareness, needs, preferences, expectations, and satisfaction across these interactions. 
However, meeting these challenges is prompting the public sector to explore new sustainable models for service delivery - models that can significantly improve customer experience and outcomes through enhanced service levels at the same or reduced cost (Bannister \& Connolly, 2012). The solution lies in developing citizen-centric models that draw inspiration from the relative success with which the private sector has addressed the situation. These examples keep the customer at the core of every decision, from strategy formulation and design through to execution. The development of citizencentric models calls for customer insight, looking at customers' wants and needs (both demographic and attitudinal), in a holistic manner - distinguishing means and ends, focusing on improved customer journeys and measurable benefits, and understanding the strategic risks associated with various service delivery models (Blackburn, 2014). In rising to the challenge, public sector Departments or Agencies across the globe are increasingly adopting a OneStop Shop citizen-centric service delivery model 90 . The concept of One-Stop Shops is to enable citizens and customers to have a single access point to information and service transactions (Bourgault \& Gusella, 2001). Some key elements which these and other governments have sought to address in the design and delivery of a customer centric model include:

- Speed: The time taken to deliver a service should be the shortest as possible for both the customer and the agency while still ensuring outcomes are delivered right the first time.

- Engagement: The way in which services are delivered should be seen as citizen-centric.

- Responsive: There should be an 'intelligent' mechanism in place to address any variation in meeting service levels and drive any changes required.

- Value: The customer needs to believe that the One-Stop Shop is cost effective, and value is driven by customer outcomes, not agency or department processes.

- Integration: A One-Stop Shop should be seamlessly integrated, and there should be no 'wrong door' policy for the citizen/customer.

\section{Overview}

Administrative services in Kosovo today, despite the long term activities to implement reforms in the administrative procedures for the last years, still prove to be complex. If there is an analysis of the administrative services in Kosovo, the notice will be that for an average government to citizen administrative service, such as Income taxes, Job search services, Social security benefits, Personal documents, Birth and Marriage Certificates etc., the citizen must obtain and submit several required documents. For one administrative service, two, three or more documents in average are needed, 
and in some cases even more documents are needed. The documents submitted by the citizens contain data which is already stored in the registries and databases of other institutions (or in some cases the same institution). These complex administrative procedures are time and money consuming for the end-users of the services and, on the other hand, it produce costs for the institutions as well (Choudrie \& Weerrakody, 2007).

These processes would be significantly simplified if institutions share the data among themselves, and if citizens would only be asked to fill out an application and pay to complete the service (Gottschalk, 2009). The basic idea of a one-stop shop is that the citizen only has to be in contact with one single entity to get information, obtain all necessary paperwork, and make applications, rather than having to go through a labyrinth of different government bodies (Christensen \& Lægreid, 2012). This has, in many cases, a positive effect on reducing corruption incidents and in simplifying administrative procedures. Processes relating to almost all public can be concentrated in a single contact point operating at the level closest to the citizens (Clarke, 2007). There, citizens can get information about required processes and necessary documents, fill application forms, submit applications, and receive the required documentation or even the payment of benefits. Public service one-stop shops could also constitute the "entrance point" to the overall public service system and could (besides information, applications etc.) assess the needs of beneficiaries and direct them to the competent services. In the context of Kosovo, one-stop shops need to be multifunctional in order to cater for a number of needs.

\section{Current Environment}

Seen from the perspective of potential sources of information, important for the OSS, there are a number of addresses where you can find the appropriate information, document, guideline, etc., for example:

- Central Registry of Permits and Licenses (lejelicenca.rks-gov.net)

- Business Registration Agency, Ministry of Trade and Industry (arbk.rks-gov.net)

Nevertheless, there is no single address where citizens, future entrepreneurs, and existing businesses can easily obtain all relevant information on the personal requirements and personal documents, business and legal environment. A basic problem in most transition countries is to find ways to guarantee the access of all potential users to modern public services and benefits which are consolidated in national legislation. The constitutional consolidation and the legal regulation of public service provision to citizens are not sufficient in themselves for guaranteeing access to benefits and services, unless they are accompanied: 
a) By systematic information and awareness of the citizens/claimants of benefits and services on their rights and the procedure to exercise them.

b) By the organization of public administration in a way that allows the effective exercise of the rights consolidated and ensures easy and unlimited access to services and benefits.

\section{Methodology and Scope}

During the creation of this document, the mixt methodology will be used using primary, secondary and tertiary data (research based documents, workshops, interview including all relevant stakeholders). Also, the comparison of OSS models from different countries is taken into account in order to have clear idea about the OSS Model that will be implemented in Kosovo. To make the OSSs more responsive to the citizen and business's needs and tackle the shortcomings, it is important to use the best practices from EU, where the Commission and the Member States agreed on a PSC Charter in 2013, setting out four standard criteria for improving and benchmarking. These four standard criteria are:

- Quality and availability of information,

- Trans actionality of e-procedures,

- Accessibility for cross-border users and

- Usability.

It has often been proven true that one of the major obstacles that citizens faced, while in need of an administrative service from a municipality or central level, was to find the right department for the specific-service. Citizens had to run up and down to several departments in order to complete their files that were utmost needed to obtain the required service. The search for the right department was not only time consuming, but was also a financial burden for citizens (Dutil, Howard, Langford \& Roy, 2008). In Kosovo, citizens have had much difficult time running after documents and stamps, since the administration, due to the lack of office facilities spread into several buildings in the central and local municipality level. In addition, due to the lack of sufficient office facility, officials were usually urged to share office space. Since they have to deal with citizens and their requirements on a daily basis, sharing their office space with other colleagues poses inconvenience, both to them and their colleagues. Thus, this resulted to a decrease in the level of efficiency of public service delivery activities.

The scope and aim of the OSS is to improve service delivery and life for citizens. A One-Stop Shop can make it possible for a public administration by taking all necessary steps for reaching a certain goal at one single place. A One-Stop Shop gives the possibility to all citizens to address all their requirements for the services in one place. All the transactions between the 
OSS and the public service departments are undertaken by the OSS staff on behalf of the citizens.

\section{Objectives and Purpose of the Research}

- The main objective is creating and setting up the road map for the establishment of OSS in Kosovo in order to increase the quality of services, facilitate the business doing, and overall improve the quality of life of its citizens.

- The audience for this document includes both internal and external stakeholders. Internal stakeholders should be defined through the process of involvement in the establishment, operationalization and monitoring process about the function of such points, whereas the external stakeholders will include beneficiaries/citizens, business owners, and other interested parties.

- Based on this, the objectives to be fulfiled are:

- Bringing an institutional systemic change

- Making public delivery systems efficient and corruption free

○ Go paperless and Go Green in midterm strategy

- The rationale for this document is based on the following aims:

- To identify the process or functionality differences between the current and proposed system

- To determine how to eliminate or minimize the gap between the current and proposed systems

Table 1. Options summary for the proposed OSS aproach in Kosovo

\begin{tabular}{|c|c|c|c|}
\hline \multicolumn{4}{|l|}{ Options Summary } \\
\hline Options & Option 1 & Option 2 & Option 3 \\
\hline $\begin{array}{l}\text { Main option } \\
\text { characteristics }\end{array}$ & $\begin{array}{l}\text { Status quo } \\
\text { Current } \\
\text { unchanged }\end{array}$ & $\begin{array}{l}\text { Extension of Service } \\
\text { Points by different } \\
\text { institutions so-called the } \\
\text { One-Stop Shop }\end{array}$ & $\begin{array}{l}\text { Change of the actual situation- } \\
\text { Creating Centers for Provision } \\
\text { of Citizen Services - Integrated } \\
\text { One-Stop Shops }\end{array}$ \\
\hline $\begin{array}{l}\text { Population / Sector / } \\
\text { Target } \\
\text { Segment }\end{array}$ & $\begin{array}{l}\text { All parties directly or } \\
\text { indirectly involved } \\
\text { (government bodies- } \\
\text { central and local level, } \\
\text { businesses, } \\
\text { individuals and all } \\
\text { natural and legal } \\
\text { persons), reliable } \\
\text { services related to } \\
\text { public administration } \\
\text { and public services } \\
\text { throughout the } \\
\text { country, Kosovo. }\end{array}$ & $\begin{array}{l}\text { All parties directly or } \\
\text { indirectly involved } \\
\text { (government bodies- } \\
\text { central and local level, } \\
\text { businesses, individuals } \\
\text { and all natural and } \\
\text { legal persons), reliable } \\
\text { services related to } \\
\text { public administration } \\
\text { and public services } \\
\text { throughout the country, } \\
\text { Kosovo. }\end{array}$ & $\begin{array}{l}\text { All parties directly or indirectly } \\
\text { involved (government bodies- } \\
\text { central and local level, } \\
\text { businesses, individuals and all } \\
\text { natural and legal persons), } \\
\text { reliable services related to } \\
\text { public administration and public } \\
\text { services throughout the country, } \\
\text { Kosovo. }\end{array}$ \\
\hline $\begin{array}{l}\text { Characteristics of } \\
\text { implementation - who } \\
\text { is responsible - for a }\end{array}$ & $\begin{array}{l}\begin{array}{l}\text { Local and } \\
\text { government, } \\
\text { enterprises }\end{array} \\
\text { public } \\
\end{array}$ & $\begin{array}{lr}\text { Ministry of } & \text { Public } \\
\text { administration, } & \text { AIS },\end{array}$ & $\begin{array}{l}\text { Ministry of } \\
\text { administration, }\end{array} \quad \begin{array}{r}\text { Public } \\
\text { Local }\end{array}$ \\
\hline
\end{tabular}




\begin{tabular}{|c|c|c|c|}
\hline $\begin{array}{lr}\text { government } & \text { body } \\
\text { (which), } & \text { private } \\
\text { sector, citizens } & \\
\end{array}$ & & $\begin{array}{l}\text { Local governance } \\
\text { bodies }\end{array}$ & $\begin{array}{l}\text { governance bodies, Prizren } \\
\text { Municipality, Civil society }\end{array}$ \\
\hline $\begin{array}{l}\text { Administration or } \\
\text { implementation of the } \\
\text { program or service }\end{array}$ & $N / A$ & $\begin{array}{lrr}\text { Ministry of } & \text { Public } \\
\text { administration, } & \text { AIS, } \\
\text { Local } & \text { governance } \\
\text { bodies } & & \end{array}$ & $\begin{array}{lr}\begin{array}{l}\text { Ministry of } \\
\text { administration, } \\
\text { governance bodies }\end{array} & \text { Public } \\
& \text { Local }\end{array}$ \\
\hline $\begin{array}{l}\text { Laws, sub-legal acts, } \\
\text { amendments } r \text { to } \\
\text { existing laws as well } \\
\text { as enforcement and } \\
\text { punishments }\end{array}$ & $\begin{array}{l}\text { The Law on Local } \\
\text { Self-Government, } \\
\text { Law on administrative } \\
\text { procedures, } \\
\text { Law no. 04 / L-094 on } \\
\text { Information Society } \\
\text { Services; } \\
\text { Tbc..... }\end{array}$ & $\begin{array}{l}\text { Review and completion } \\
\text { of the legal framework } \\
\text { for the enhancing of the } \\
\text { services at OSS (Review } \\
\text { of Law overlapping, } \\
\text { Administrative orders, } \\
\text { Regulations and } \\
\text { decisions) }\end{array}$ & $\begin{array}{l}\text { Review and completion of the } \\
\text { legal framework for the } \\
\text { enhancing of the services at OSS } \\
\text { (Review of Law overlapping, } \\
\text { Administrative orders, } \\
\text { Regulations and decisions) }\end{array}$ \\
\hline $\begin{array}{l}\text { Economic stimuli or } \\
\text { incentives - subsidies } \\
\text { or taxes }\end{array}$ & $N / A$ & $\begin{array}{l}\text { Reconstruction } \\
\text { investments }\end{array}$ & $\begin{array}{l}\text { Reconstruction investments } \\
\text { Trainings and capacity building }\end{array}$ \\
\hline $\begin{array}{l}\text { Education } \quad \text { and } \\
\text { Communication } \\
\text { Campaigns }\end{array}$ & N/A & $\begin{array}{l}\text { There will be a need for } \\
\text { a promotional and } \\
\text { awareness campaign. }\end{array}$ & $\begin{array}{l}\text { There will be a need for further } \\
\text { education, trainings, as well } \\
\text { promotional and awareness } \\
\text { campaign. }\end{array}$ \\
\hline $\begin{array}{l}\text { Administrative orders } \\
\text { and regulations }\end{array}$ & Review of legal acts & Review of legal acts & $\begin{array}{l}\text { Review of legal acts and } \\
\text { avoiding the overlapping of } \\
\text { legal basis for basket of services } \\
\text { provided in OSS }\end{array}$ \\
\hline $\begin{array}{l}\text { Time limits - when the } \\
\text { option is effective }\end{array}$ & $x$ & $x$ & $2018 / 19$ \\
\hline
\end{tabular}

\section{OSS Models and Experiences: Comparison of Different Countries}

The need for more efficient, effective, and qualitative provision of services to citizens is nowadays of utmost importance in all modern states. The inability of the traditional and bureaucratic public administration to effectively meet citizens` needs has led to the necessity to search for new methods with regards to the structure and operation of the public sector (Fimreite \& Laegreid, 2009). Below is a comparison and some of the examples on how different states have used different approaches for the establishment of OSS in their countries. This is with the aim to see which is the most suitable solution for Kosovo in its path towards OSS establishment. 
Table 2. OSS Models and experiences: comparison of different countries

\begin{tabular}{|c|c|c|c|c|c|c|}
\hline Country & $\begin{array}{l}\text { Local } \\
\text { Name }\end{array}$ & Services Provided & Distribution & Administration & Remarks & $\begin{array}{c}\text { Fee } \\
\text { Charged }\end{array}$ \\
\hline Cyprus & $\begin{array}{l}\text { Citizen } \\
\text { service } \\
\text { centers } \\
(\mathrm{CSCS})\end{array}$ & \begin{tabular}{|} 
CSCS offer more than 90 different \\
services from a number of \\
governmental organizations, such \\
as issuing of birth certificates, \\
identity cards, driving licenses, \\
road tax licenses, social insurance \\
contributions records etc. In \\
addition, CSCS receive \\
applications for the issuing of \\
passports and refugee identity \\
cards, for registration in the \\
electoral register, for grants, \\
allowances, benefits and pensions.
\end{tabular} & \begin{tabular}{|} 
At present, the \\
seven CSCS \\
operating on the \\
island act as an \\
alternative \\
channel for \\
citizens to deal \\
with the public \\
administration(Fl \\
umian, M, Coe \\
A and \\
Kernaghan, K, \\
2007)
\end{tabular} & \begin{tabular}{|c|} 
The competent \\
authority for the \\
CSC, the public \\
Administration and \\
personnel department \\
(PAPD) of the \\
Ministry of Finance. \\
An important \\
stakeholder in the \\
whole project is the \\
department of \\
Information \\
Technology services, \\
which is in charge of \\
the installation and \\
support of the IT \\
systems/equipment.
\end{tabular} & \begin{tabular}{|c|} 
Quality \\
management \\
system \\
according to \\
ISO \\
9001:2008 in \\
the citizen \\
service centers \\
\end{tabular} & \\
\hline Portugal & $\begin{array}{c}\text { 'On the } \\
\text { spot } \\
\text { house' (or } \\
\text { in } \\
\text { Portuguese } \\
\text {, Casa } \\
\text { Pronta) }\end{array}$ & \begin{tabular}{|} 
a sectorial public service which \\
allows all the necessary formalities \\
to be performed for the purchase \\
and sale of homes (buildings), \\
with or without a mortgage, the \\
transfer of a bank loans to \\
purchase a house and other \\
housing contracts, in a single \\
window service
\end{tabular} & \begin{tabular}{|c|} 
This service \\
became available \\
on 24 July 2007, \\
at seven land \\
register offices, \\
five Portuguese \\
municipalities, \\
covering only \\
purchase and \\
sale
\end{tabular} & \begin{tabular}{|c|} 
Public-private \\
partnership. \\
Government agencies \\
include ministry of \\
justice, \\
representatives of all \\
civil society areas, \\
including employees' \\
and employers' \\
associations, legal \\
practitioners and \\
representatives of \\
several economic \\
activities
\end{tabular} & & \\
\hline Greece & $\begin{array}{c}\text { The } \\
\text { Citizens' } \\
\text { Service } \\
\text { Centers }\end{array}$ & $\begin{array}{c}\text { A total of } 29 \text { services are } \\
\text { available from the OSS/CCs, } \\
\text { including photocopying, printing, } \\
\text { scanning, and in most cases, sale } \\
\text { of legal stamps and vouchers for } \\
\text { recharge }\end{array}$ & \begin{tabular}{|} 
At the moment \\
around 1000 \\
citizens' centers \\
operate in the \\
local authorities \\
of the country
\end{tabular} & $\begin{array}{l}\text { At this moment, the } \\
\text { Ministry of the } \\
\text { Interior, Public } \\
\text { Administration and } \\
\text { Decentralization } \\
\text { coordinates activities }\end{array}$ & & \\
\hline Denmark & $\begin{array}{c}\text { Municipal } \\
\text { Centers }\end{array}$ & $\begin{array}{l}\text { Information on } \\
\text { employment, employment } \\
\text { insurance, social security }\end{array}$ & 77 municipalities & \begin{tabular}{|c|} 
Responsibilities \\
shared \\
between national and \\
municipal \\
governments
\end{tabular} & \begin{tabular}{|c|} 
Model \\
representing \\
cohabitation of \\
services re \\
integration \\
\end{tabular} & \\
\hline
\end{tabular}




\begin{tabular}{|c|c|c|c|c|c|c|}
\hline Georgia & \begin{tabular}{|c|} 
Communit \\
y \\
Centers, \\
Public \\
Service \\
Halls
\end{tabular} & $\begin{array}{c}\text { The Public Service Hall is a public } \\
\text { space to deliver approximately } 300 \\
\text { services nationwide which are } \\
\text { exclusively provided by the } \\
\text { Ministry of Justice, Government } \\
\text { of Georgia }\end{array}$ & & $\begin{array}{c}\text { The operation is } \\
\text { maintained by the } \\
\text { municipal authorities } \\
\text { under an agreement } \\
\text { executed between } \\
\text { local authorities and } \\
\text { Public Service } \\
\text { Development Agency } \\
\text { (PSDA). The } \\
\text { operators serving at } \\
\text { the centers are } \\
\text { employees of the } \\
\text { concerned municipal } \\
\text { authority. }\end{array}$ & $\begin{array}{c}\text { OSS used as a } \\
\text { vehicle of } \\
\text { recentralizatio } \\
n\end{array}$ & \\
\hline Norway & $\begin{array}{l}\text { NAV } \\
\text { centers }\end{array}$ & $\begin{array}{c}\text { Information on } \\
\text { employment and social security }\end{array}$ & $\begin{array}{c}\text { All } \\
\text { municipalities }\end{array}$ & $\begin{array}{c}\text { New Employment } \\
\text { and } \\
\text { Welfare } \\
\text { Administration }\end{array}$ & \begin{tabular}{|c|} 
Services \\
integrated \\
before they \\
were brought \\
under one roof
\end{tabular} & \\
\hline $\begin{array}{l}\text { Lisbon - } \\
\text { Portugal }\end{array}$ & $\begin{array}{l}\text { SIMPLIS } \\
\text { programe }\end{array}$ & \begin{tabular}{|} 
More than 100 measures and \\
actions were taken, including: Fix \\
my street; location plans; Business \\
schedule map; personalized chat; \\
open licensing; one-stop-shop start \\
and grow; Just in Time services - \\
certified copies and plans; citizen \\
manager; and Filming in Lisbon.
\end{tabular} & Lisbon City & $\begin{array}{l}\text { Lisbon Municipality } \\
\text { administration }\end{array}$ & \begin{tabular}{|c|} 
The choice of \\
these measures \\
was not \\
random. The \\
survey resulted \\
that $70 \%$ of \\
the overall \\
measures need \\
to be improved
\end{tabular} & $\begin{array}{c}\text { In most } \\
\text { cases, yes } \\
\end{array}$ \\
\hline Albania & $\begin{array}{c}\text { Integrated } \\
\text { Citizen } \\
\text { Service } \\
\text { Centers }\end{array}$ & $\begin{array}{c}\text { Functions and responsibilities of } \\
\text { Integrated Citizen Service Centers } \\
\text { include but are not limited to: } \\
\text { Provide services in integrated } \\
\text { counters for citizens } \\
\text { Participates in the drafting of } \\
\text { procedures and standards for front } \\
\text { office and back office offices, } \\
\text { Monitor the quality and } \\
\text { transparency of providing services } \\
\text { to the citizen at the front office } \\
\text { Conducts ongoing training for the } \\
\text { front desk staff of the front desk } \\
\text { Build and manage centers offering } \\
\text { one-stop-shop integrated public } \\
\text { services, } \\
\text { Ensures access to all citizens and } \\
\text { the accuracy of information on } \\
\text { administrative procedures through } \\
\text { various modern communication } \\
\text { channels } \\
\text { Perform regular optimization of } \\
\text { administrative processes in all } \\
\text { public institutions } \\
\text { Drafts and updates standard forms } \\
\text { for receiving public services and } \\
\text { maintains their bank to be } \\
\text { accessed by any public } \\
\text { administration employee }\end{array}$ & $\begin{array}{c}\text { One-stop } \\
\text { services centers } \\
\text { are already } \\
\text { functional and } \\
\text { serve the citizens } \\
\text { in Kavajë and } \\
\text { Kruja and are } \\
\text { expected to be } \\
\text { followed by } \\
\text { integrated } \\
\text { centers in Fier } \\
\text { and Gjirokastra, } \\
\text { while by 2020 } \\
\text { Integrated } \\
\text { Citizen Service } \\
\text { Centers will } \\
\text { extend their } \\
\text { activities }\end{array}$ & ADISA & \begin{tabular}{|} 
OSS is the \\
main \\
public service \\
delivery \\
mechanism
\end{tabular} & \\
\hline
\end{tabular}




\section{OSS Model Proposal for Transition Countries: Case of Kosovo}

The examples surveyed above show a rich diversity of OSS models available. One of the primary concerns in the design of OSS has been the integration of services (Gagnon, Posada, Bourgault et al., 2010). As seen in the examples of Norway and Denmark, services can cohabit in an OSS with or without prior integration. For efficiency purposes, integration of the service delivery lines at the department lines before cohabitation at the OSS seems advisable. This would ensure that the structure of the OSS is kept simple for the citizens, who may not be aware of the various channels from which services are provided to them. Furthermore, examining the overall characteristics of the various available models of OSS, it is a key element that the suggestion they have should include the following broad dimensions: structural, administrative, and social.

- The structural dimension of OSS relates to issues of design, integration with government departments (in both levels), geographical distribution, selection of the basket of services, etc. The structural dimension becomes a challenge where there is a high fragmentation of government departments, more so in cases where the departments do not interact much with each other (Gortmaker, Janssen \& Wagenaar, 2005). Included in the structural dimension is the vertical and horizontal integration of government structures and functions. Vertical integration refers to integrating the services of different levels of government, while horizontal integration refers to integrating the services spread across one level of government.

- The administrative dimension, meanwhile, refers to the bureaucratic arrangements required to cater for the demands of the citizens (Countryside Agency, 2003).

- The social dimension relates to issues of social justice that provide the background for the establishment of an OSS. Government should take into acount that the setting up of OSS should be premised on the social commitment of making public services available to citizens (Ole Kristian Sandnes Håvold, Ivan Harsløf \& Tone Alm Andreassen, 2017). Thus, constraints, such as lack of internet facilities or geographical barriers, should not be the reason for not providing such improved services.

Having in mind all factors affecting the situation in public services in Kosovo, the third alternative is the best solution to address the improvement of service quality to citizens and costumers. Thus, this is regarded as complex obstacles to development. Individual central institutions, municipalities, and regions can seek to fully utilize their potential as an integral part of the overall national effort for better and faster services towards their citizens and other customers. Based on socio-economic development of Kosovo, the best way to 
address such important issue is starting with pilot projects in three (3) regions or municipalities and after preparation of guidelines for the implementation process and initial evaluation to continue the process in the whole country. From the perspective of OSS implementation, the model of Albania through the Integrated Citizen Service Centers is most favorable because of many factors including:

- Level of development,

- Socio-economic aspects,

- Citizens and customers culture,

- Sharing of experience,

- Cost benefit analysis and

- Other aspects.

\section{Strategic Approach and Design of OSS in Kosovo}

Strategically, the position of the Kosovo Government about conceptual approach and design issues of OSS has to be based on suggestions that the majority of citizens who visit an e-government facility has four main objectives:

- Learn about something (information services),

- Apply for something (downloadable forms),

- Pay for something (e-transactions) or

- Complain about something.

Though this provides a glimpse of the kind of OSS facilities that can be made available, a large number of other services, such as obtaining processed services, can also be possible through such facilities. Complaint mechanisms offered by the OSS are driving accountability in many contexts. In practice worldwide, it has been identified nowadays that there are two kinds of OSS single-window services and single-door services - as illustrated in the figure below.

SINGLE WINDOW
where a citizen interacts with
only one government official,
who is trained to handle all of the
services offered through the OSS

Figure 1. OSS - single-window services and single-door services

In terms of physical architecture, various models exist, but the most common design is a single building with a range of service providers. Buildings may be owned by the local government or a public agency, or they may be leased. In terms of financing, OSS requires long term funding as short 
term funding is wasteful, given the investments required for staff training. Therefore, the following challenges exist in the designing of OSS projects:

- Large Capital Investment in Relation to the Size of the Population: A full-fledged OSS facility requires long-term capital investment in sizeable amounts to establish durable facilities.

- Partnerships: Here, OSS established might experience collision in terms of responsibilities among different governmental levels. Also, power arrangements will have to be figured out, along with sharing of responsibilities. This can result in a prolonged power tussle between the various parties involved.

- Reconciling the Needs of Different Users: Within the same services, different sections of the citizenry might have different requirements, making it difficult for the bureaucrats to cater for the differentiated requirements.

- Difficulties in Maintaining Enthusiasm and Time Commitments Among Staff: This is especially a problem when the staff is drawn from the community because of low salaries or when the OSS rely on volunteers to provide services.

Having in mind the socio-cultural aspects and economic feasibility, the approach proposed is OSS with one door approach -where the citizens will have access to several services from different institutions and levels. Beyond that, the Government of Kosovo has to concentrate their efforts in the next step to increase the role and effects of e-services through e-service portal. However, all these changes would not be feasible without modern IT, by means of which it is possible to transform the existent rigid hierarchical and strictly fragmented organizational structures of government into efficient and open network of entities. This would allow a maximally smooth execution of processes and consequently satisfy the citizens/customers' needs and expectations. The scheme of future citizens/customer driven service delivery is shown in the figure below.

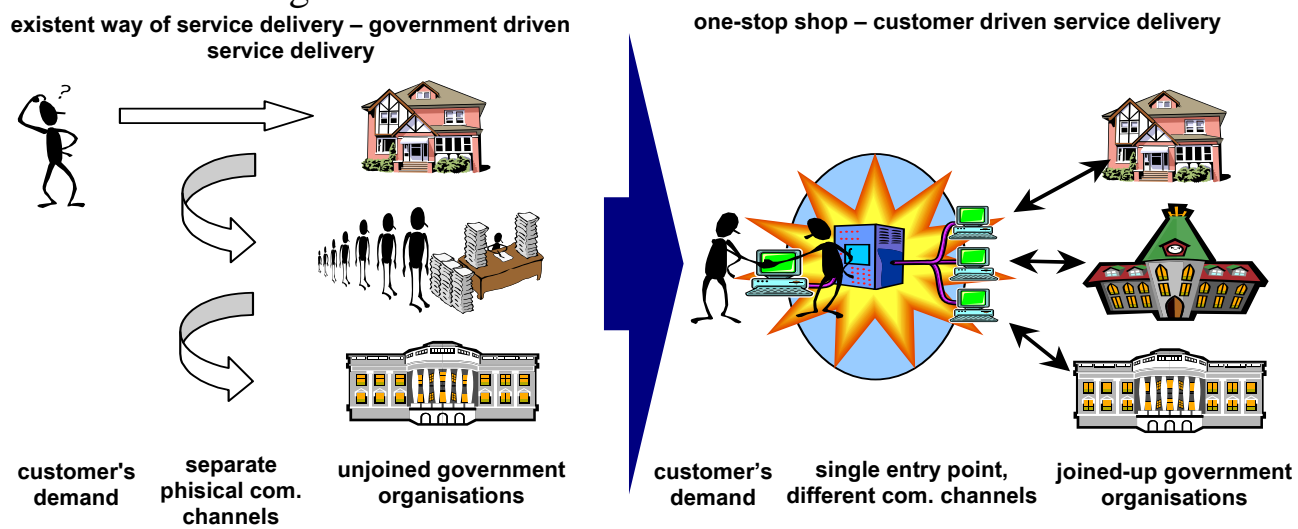

Figure 2. The scheme of future citizens/customer driven service delivery 


\section{Conclusion and Recomendations: Justification of the Alternative and Option Proposed}

Having analyzed the proposed options and liking this with the strategic approach from the perspective of public administration and modernization, and taking into account the activity action plan of the MPA, it is recommended that MPA/AIS adopt the Option 3 (three). This means that MPA/AIS should start immediately to design the guide for the implementation plan and activities toward establishment of the first OSS Pilot in the most suitable location in Kosovo. Parallel to this, the MPA/AIS has to coordinate overall activities with all stakeholders in local and central level in order to identify and involve key stakeholders in the OSS implementation process, identify needs, and finalize the basket of services to be provided according to this option in the OSS. The proposed approach in accordance with the option 3the open door approach- is most suitable for the actual stage of developments in the country which always aims for next digitalized stage in future. Therefore, the enhancement of e-service portal should be developed and maintained.

\section{Further Steps}

The concept document will serve as road for future activities. Also, the concept paper has to be followed by the implementation plan and steps where the chosen model will be piloted and a working group monitoring the steps will be established. In this regard, in order to begin the pilots, it is necessary that GAP Analysis, List of integrated services, training needs, and follow up actions with timetables should be identified.

\section{References:}

1. Anthopoulos, LG., Siozos, P. \& Tsoukalas, IA. (2007). Applying participatory design and collaboration in digital public services for discovering and re-designing e-Government services. Government Information Quarterly, 24: 353 - 376.

2. Askim, J., Fimreite, AL., Moseley, A. \& Pederson, LH. (2011). Onestop shops for social welfare: the adaptation of an organizational form in three countries. Public Administration, 89: 1451 - 1468.

3. Aucoin, $P$ (2002). Beyond the 'new' in public management reform in Canada: catching the next wave? The Handbook of Canadian Public Administration, 36 - 52.

4. Bannister, F. \& Connolly, R. (2012). Forward to the past: lessons for the future of e-government from the story so far. Information Polity, 17: $211-226$. 
5. Blackburn, G. (2014). Elements of successful change: the service Tasmania experience to public sector reform. Australian Journal of Public Administration, 73: 103 - 114.

6. Bourgault, J. \& Gusella, M. (2001). Performance, pride and recognition in the Canadian federal civil service. International Review of Administrative Sciences, 67: 29 - 47.

7. Choudrie, J. \& Weerrakody, V. (2007). Horizontal process integration in e-government: the perspective of a UK local authority. International Journal of Electronic Government Research, 3: 22.

8. Christensen, T. \& Lægrei, P. (2011). Complexity and hybrid public administration-theoretical and empirical challenges. Public Organization Review, 11: 407 - 423.

9. Christensen, T. \& Lægreid, P. (2012). Competing principles of agency organization-the reorganization of a reform. International Review of Administrative Science, 78: 579 - 596.

10. Clarke, J. (2007). Citizen-consumers and public service reform: at the limits of neoliberalism? Policy Futures in Education, 5: 239 - 248.

11. Countryside Agency (2003). Setting up One Stop Shops: A good practice handbook on linking services in market towns.

12. Dutil, PA., Howard, C., Langford, J. \& Roy, J. (2008). Rethinking government-public relationships in a digital world: customers, clients, or citizens? Journal of Information Technology \& Politics, 4:77 - 90.

13. Fimreite, AL. \& Laegreid, P. (2009). Reorganizing the welfare state administration: partnership, networks and accountability, Public Management Review, 11: 281 - 297.

14. Flumian, M., Coe, A. \& Kernaghan, K. (2007). Transforming service to Canadians: the Service Canada model. International Review of Administrative Science, 73: 557 - 568.

15. Gagnon,Y-C., Posada, E., Bourgault, M. et al. (2010). Multichannel delivery of public services: a new and complex management challenge. International Journal of Public Administration. 33: 213 - 222.

16. Gortmaker, J., Janssen, M. \& Wagenaar, RW. (2005). Towards requirements for a reference model for process orchestration in eGovernment, E-Government: Towards Electronic Democracy, Springer, $169-180$.

17. Ole Kristian Sandnes Håvold, Ivan Harsløf \& Tone Alm Andreassen (2017). Externalizing an 'Asset Model' of Activation: Creative Institutional Work by Frontline Workers in the Norwegian Labour and Welfare Service, Social Policy \& Administration, 52, 1, (178-196). 